than by any other physiological variable. This is not to say, however, that there are not other factors (such as acid-base balance and congenital anomalies) which affect this process, just as there are many influences besides parathyroid hormone which determine plasma calcium.

\section{References}

Anderson, J. \& Parsons, V. (1963) The tubular maximal resorptive rate for inorganic phosphate in normal subjects. Clin. Sci. 25, 431.

BiJVoet, O.L.M. \& BloedSPIEgel (1967) Tubulair Maximum en Uitscheiding van Fosfaat. Dessain, Mechelen.

EDwards, N.A. \& Hodgkinson, A. (1965) Studies of renal function in patients with idiopathic hypercalciuria. Clin. Sci. 29, 327.

Harden, R.McG., Harrison, M.T. \& Alexander, W.D. (1963) Phosphate excretion and parathyroid function after radioiodine therapy and thyroidectomy. Clin. Sci. 25, 27.

Hodgkinson, A. (1963) Biochemical aspects of primary hyperparathyroidism. Clin. Sci. 25, 21.

Janse, H., van Gelderen, H.H. \& RuYs, J.H. (1966) Assessment of urinary phosphate excretion in normal and abnormal children. Arch. Dis. Childh. 41, 541.

Kyle, L.H., SchaAf, M. \& Canary, J.J. (1958) Phosphate clearance. Amer. J. Med. 24, 240.
Lambert, P.P., van Kessel, E. \& Leplat, C. (1947) Etude sur l'elimination des phosphates inorganiques chez l'homme. Acta med. scand. 128, 386.

Milne, M.D., Stanbury, S.N. \& Thomson, A.E. (1952) Observations on Fanconi Syndrome and renal hyperchloraemic acidosis in adults. Quart. J. Med. 21, 61.

Nordin, B.E.C. (1964) Tests for parathyroid function. Postgrad. Med. 35, 42.

NordIN, B.E.C. (1961) Biochemical aspects of parathyroid function and hyperparathyroidism. Advanc. clin. Chem. 4, 275.

Nordin, B.E.C. \& Fraser, R. (1954) The effect of intravenous calcium on phosphate excretion. Clin. Sci. 13, 477.

Nordin, B.E.C. \& FraSER, R. (1960) Assessment of urinary phosphate excretion. Lancet, i, 947.

Nordin, B.E.C. \& SMITH, D.A. (1965) Diagnostic Procedures in Disorders of Calcium Metabolism. Churchill, London.

PitTs, R.F., Ayer, J.L. \& Schiess, N.A. (1949) The renal regulation of acid base balance in man. III. The reabsorption of bicarbonate. J. clin. Invest. 28, 35 .

ReYnolds, T.B., Lanman, H. \& Tupikova (1960) Maximum tubular reabsorption of phosphate (TmP) in hyperparathyroidism. J. clin. Endocr. 20, 1136.

SMiTH, D.A. \& Nordin, B.E.C. (1964) The effect of a high phosphorus intake on total and ultrafilterable plasma calcium and on phosphate clearance. Clin. Sci. 26, 279.

Thomas, W.C., Connor, T.B. \& Morgan, H.G. (1959) Medical progress: diagnostic considerations in hypercalcaemia with discussion of various means by which such a state may develop. New Engl. J. Med. 260, 591.

\title{
The Achilles tendon reflex as an index of thyroid function
}

\author{
GeORge Nuki R. I. S. BAYLISS
}

Westminster Hospital and Medical School, London

THIS PAPER is dedicated with affection to John McMichael who so rightly taught one of us that in the practice of medicine mensuration was often the great corrective to that important but potentially misleading entity known as 'clinical impression'.

\section{Introduction}

In 1884 William Ord reported that the tendon reflexes elicited on clinical examination were prolonged in patients with myxoedema. Not until 40 years later was this prolongation recorded graphically (Chaney, 1924); the converse shortening of the reflex time in thyrotoxic patients was first demonstrated in 1929 (Fournier). Subsequently a number of workers using various recording devices have measured the tendon reflexes in patients with thyroidal dysfunction (Harrell \& Daniel, 1941 ; Lambert et al., 1951 ; Lawson, 1958 ; Gilson, 1959 ; Sharpe, 1961 ; Fogel et al., 1962 ; Fejer \& Kun, 1963 ; Sherman, GoldG berg \& Larson, 1963 ; Smart \& Robson, 1963 ; Moulopoulas, Koutras \& Kralios, 1964; Reinfrank et al., 1967).

Today two main techniques are used, the photomotogram (Gilson, 1959) and the kinemometer (Lawson, 1958). In the former the movement of the sole of the foot, after percussion of the Achilles tendon, interrupts a light path which transmits a signal via a photo-electric transducer to an electrocardiographic (ECG) machine and writes a tracing as shown in Fig. 1(a). Thyroidal function has been assessed from either the 'half-relaxation time' or the 'relaxation time' (Fig. 1a). The kinemometer is an electromagnetic device. A magnet is attached to the sole of the patient's foot and on percussion this moves into an electrical field inducing a current which is transmitted to an ECG machine. A tracing is written as shown in Fig. 1(b). The time from stimulation to the end of contraction or from maximal contraction to maximal relaxa- 
tion ('the valley-to-peak time') is used as an index of thyroidal function.

There is no general agreement as to the usefulness of these measurements as an index of thyroidal activity and it is appreciated that a variety of non-thyroidal conditions such as neurological disorders and ankle oedema may falsify the results.

The purpose of this paper is to relate our experience with the photomotographic method in all patients referred to an outpatient clinic for assessment of thyroid function over a period of 4 years.

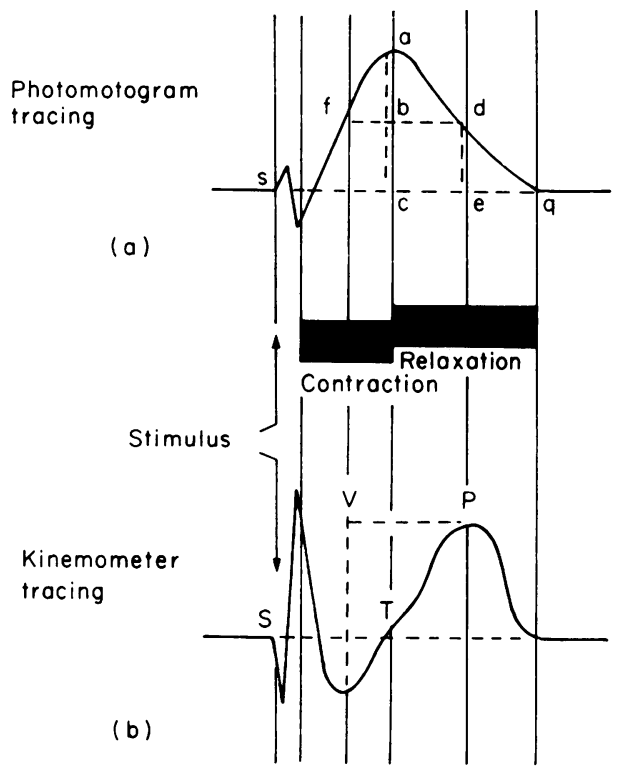

FIG. 1. Diagrammatic representation of the Achilles tendon reflex recorded by photomotography (a) and by kinemometry (b). ab = bc. The 'half-relaxation-time' is represented by se; the 'relaxation time' by sq and the 'half-contraction-to-half-relaxation time' by fd. The 'valley-to-peak' time is represented by VP and the 'contraction time' by ST.

\section{Methods and patients}

The Achilles tendon reflexes were recorded by one observer (R.I.S.B.) with the patient kneeling on a pillow covering the seat of a wooden chair. An ordinary patellar hammer was used. The photomotographic machine was made by the Department of Clinical Measurement and the tracing recorded on an ECG machine calibrated to give $1 \mathrm{~cm}$ deflection with 1 millivolt and at a paper speed of $25 \mathrm{~mm} / \mathrm{sec}$. About ten tracings were made from each patient. The first three or four tracings and any showing artefacts were discarded; thereafter three to five tracings were mounted on a card for later measurement.
The measurements were all made by another observer (G.N.) to the nearest $10 \mathrm{msec}$ on the shortest of the mounted tracings. This was done without knowledge of the clinical state of the patient or of results of the other tests of thyroid function.

Evaluation of the patient's thyroid status was made before measurement of the ankle reflex time and was based on a variety of parameters described elsewhere (Hobbs, Bayliss \& Maclagan, 1963 ; Bayliss, 1967a, b) including protein-bound iodine, uptake of ${ }^{132} \mathrm{I}$, the tri-iodothyronine suppression test, the thyrotropin stimulation test, changes in the serum cholesterol and ECG in response to thyroxine treatment, prolonged clinical assessment and the response to treatment.

Tracings were recorded from 232 consecutive patients who were referred for assessment of thyroid function. Some were already being treated with thyroid extract or thyroxine; others were receiving antithyroid drugs or had been treated by thyroidectomy or radioiodine in the past. Assessment of thyroid function by chemical or isotopic methods was made in close temporal proximity to recording the photomotogram. Twelve patients were discarded because a certain assessment of thyroidal function could not be made due to incomplete or equivocalo results.

\section{Results}

The final assessment of thyroid status without reference to the photomotogram, the sex and ages of the 220 patients are shown in Table 1 .

TABLE 1

Final assessment of thyroid function in 220 patients

\begin{tabular}{lcccc}
\hline $\begin{array}{c}\text { Thyroid } \\
\text { status }\end{array}$ & Total & Male & Female & $\begin{array}{c}\text { Mean age } \\
\text { (yr) } \\
\text { and range }\end{array}$ \\
\hline Euthyroid & 116 & 24 & 92 & $43(10-71)$ \\
Hyperthyroid & 62 & 9 & 53 & $43(14-77)$ \\
Hypothyroid & 42 & 1 & 41 & $48(19-74)$ \\
\hline
\end{tabular}

The half-relaxation time and half-contractionto-half-relaxation time were measured in all subjects. The distribution curve of the half-relaxation time (HRT) in these patients is shown in Fig. 2. Plotted on a linear arithmetric scale the curve is skewed to the right (above), but when plotted on a logarithmic scale it assumes a more 'normal' distribution (below).

The mean values, standard deviations, $95 \%$ confidence limits and coefficients of variation in the euthyroid, hyperthyroid and hypothyroid groups are shown in Table 2 . The antilogarithms 

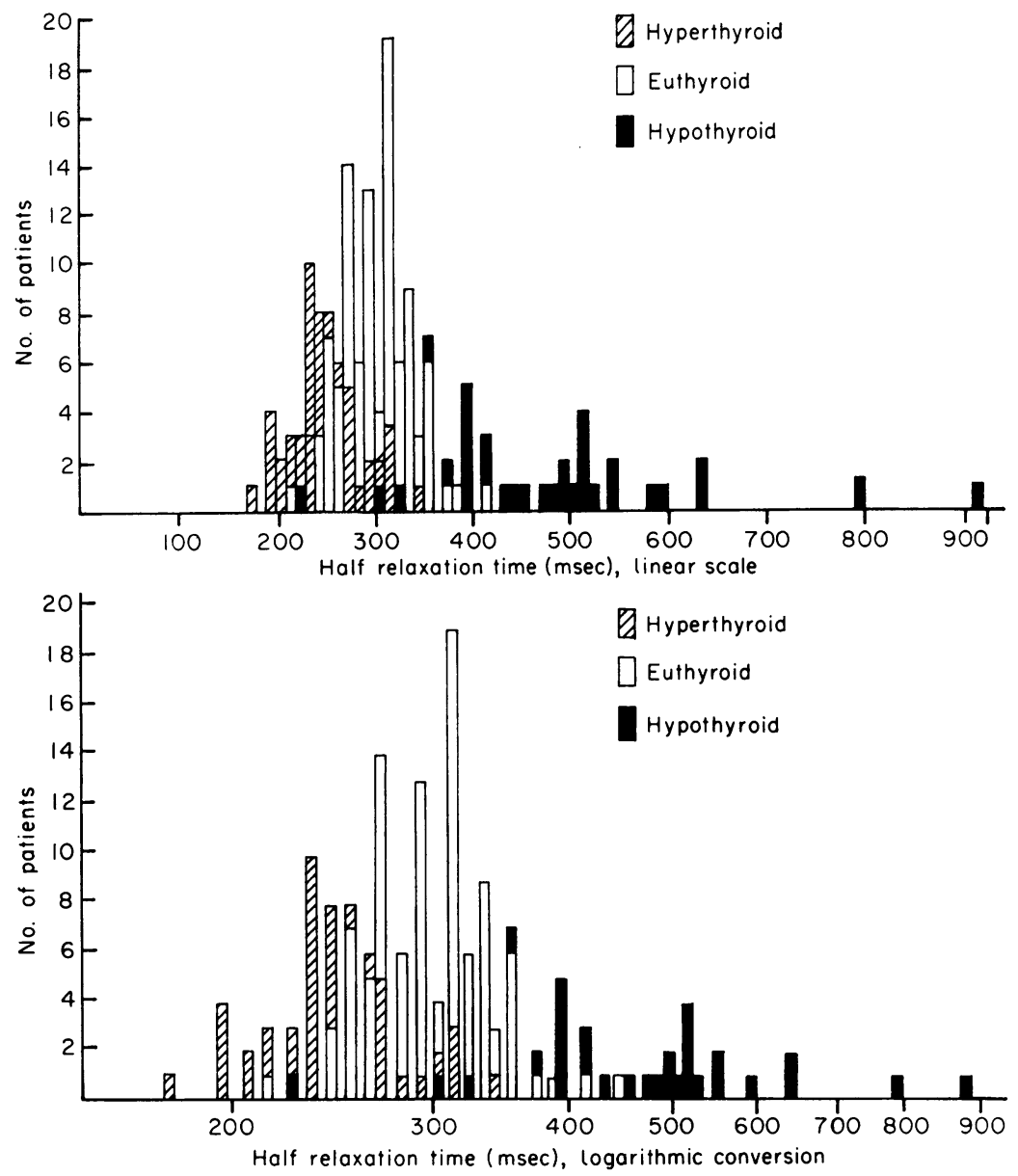

FIG. 2. The distribution of the 'half-relaxation time' in hyperthyroid, euthyroid and hypothyroid patients on a linear scale (above), and on a logarithmic scale (below).

of the results derived from the logarithmic scale are tabulated for convenience of comparison. The half-contraction-to-half-relaxation time gives a poorer discrimination between each group than does the half-relaxation time, and the latter gives a significantly better discrimination when plotted on a logarithmic scale. For this reason the halfrelaxation time derived from the logarithmic scale is only considered further.

\section{Euthyroid patients}

No attempt was made to establish normal values of HRT in healthy controls unsuspected of thyroid disease. Our normal range was derived from the 116 patients finally judged to be euthyroid by other criteria than the ankle reflex time. The mean HRT for the whole group was $310 \mathrm{msec}$ (range 250-380) (Table 2). The results are influenced in slight degree by the patient's sex and age. Thus the mean HRT for the twentyfour euthyroid males was $310 \mathrm{msec}$ (SD 40) as compared with a mean of 290 msec (SD 40) in the ninety-two euthyroid females, a statistically significant difference $(0.025<P<0.05)$. The mean HRT for the thirty euthyroid patients aged 11-30 years was $300 \mathrm{msec}$ (SD 25); $310 \mathrm{msec}$ (SD 45) for the forty-three subjects aged 31-50; and $330 \mathrm{msec}$ (SD 45) for the thirty-two older subjects aged 51-70. The difference between the oldest and the other two age groups is significant $(P<0.0025)$.

The results for the patients with hypo- or hyper-thyroidism are given in Table 2 and shown graphically in Fig. 3 . Table 3 is an analysis of the numbers and percentages falling 
into each diagnostic category when judged by the HRT.

TABLE 2

Comparative results of ankle reflex times

\begin{tabular}{|c|c|c|c|}
\hline & \multicolumn{2}{|c|}{$\begin{array}{l}\text { Half-relaxation time } \\
(\mathrm{msec})\end{array}$} & \multirow{2}{*}{$\begin{array}{l}\text { Half- } \\
\text { contraction } \\
\text { to half- } \\
\text { relaxation } \\
\text { time (msec) }\end{array}$} \\
\hline & $\begin{array}{l}\text { Log } \\
\text { scale }\end{array}$ & $\begin{array}{l}\text { Linear } \\
\text { scale }\end{array}$ & \\
\hline \multicolumn{4}{|l|}{ Euthyroid (116 cases) } \\
\hline Mean & 310 & 320 & 210 \\
\hline Standard deviation & $30-35$ & 40 & 40 \\
\hline Normal range* & $250-380$ & $240-400$ & $130-290$ \\
\hline Coefficient of variation & $11 \%$ & $12 \cdot 5 \%$ & $19 \%$ \\
\hline \multicolumn{4}{|l|}{ Hypothyroid (42 cases) } \\
\hline Mean & 440 & 470 & 350 \\
\hline Standard deviation & $60-70$ & 120 & 105 \\
\hline Normal range & $300-660$ & $230-710$ & $140-560$ \\
\hline Coefficient of variation & $16 \%$ & $25 \%$ & $30 \%$ \\
\hline \multicolumn{4}{|l|}{ Hyperthyroid (62 cases) } \\
\hline Mean & 250 & 320 & 160 \\
\hline Standard deviation & $20-30$ & 30 & 30 \\
\hline Normal range & $210-310$ & $190-310$ & $100-230$ \\
\hline Coefficient of variation & $12 \%$ & $12 \%$ & $19 \%$ \\
\hline
\end{tabular}

* Normal range $= \pm 2 \mathrm{SD}$.

TABLE 3

Analysis of the distribution of patients according to half-relaxation time

\begin{tabular}{|c|c|c|c|c|}
\hline & \multicolumn{4}{|c|}{ Half-relaxation time } \\
\hline & \multicolumn{2}{|c|}{ Log scale } & \multicolumn{2}{|c|}{ Linear scale } \\
\hline & $\begin{array}{c}\text { No. } \\
\text { patients }\end{array}$ & $\begin{array}{c}\text { Per- } \\
\text { centage }\end{array}$ & $\begin{array}{c}\text { No. } \\
\text { patients }\end{array}$ & $\begin{array}{c}\text { Per- } \\
\text { centage }\end{array}$ \\
\hline Euthyroid patients & 116 & 100 & 116 & 100 \\
\hline Euthyroid range & 107 & 92 & 113 & 97 \\
\hline Hypothyroid range & 8 & 7 & 2 & 2 \\
\hline Hyperthyroid range & 1 & 1 & 1 & 1 \\
\hline Hypothyroid patients & 42 & 100 & 42 & 100 \\
\hline Euthyroid range & 12 & 27 & 16 & 38 \\
\hline Hypothyroid range & 29 & 71 & 25 & 60 \\
\hline Hyperthyroid range & 1 & 2 & 1 & 2 \\
\hline Hyperthyroid patients & 62 & 100 & 62 & 100 \\
\hline Euthyroid range & 35 & 62 & 47 & 76 \\
\hline Hypothyroid range & 一 & - & - & - \\
\hline Hyperthyroid range & 24 & 38 & 15 & 24 \\
\hline
\end{tabular}

\section{Hypothyroid patients}

The mean HRT for the hypothyroid patients was $440 \mathrm{msec}$ (range 300-660) and this is significantly different from the mean of $310 \mathrm{msec}$ for the euthyroid group $(P<0.0005)$. However $27 \%$ of the hypothyroid patients had a HRT in the euthyroid range and one patient overlapped into the hyperthyroid range (Fig. 3 and Table 3).
Hyperthyroid patients

The mean HRT in the hyperthyroid patients was $250 \mathrm{msec}$ (range 210-310) and this was significantly shorter than the mean of $310 \mathrm{msec}$ for the euthyroid patients $(P<0.0005)$. However, in $62 \%$ of the hyperthyroid patients the HRT fell within the euthyroid range (Fig. 3 and Table 3 ).

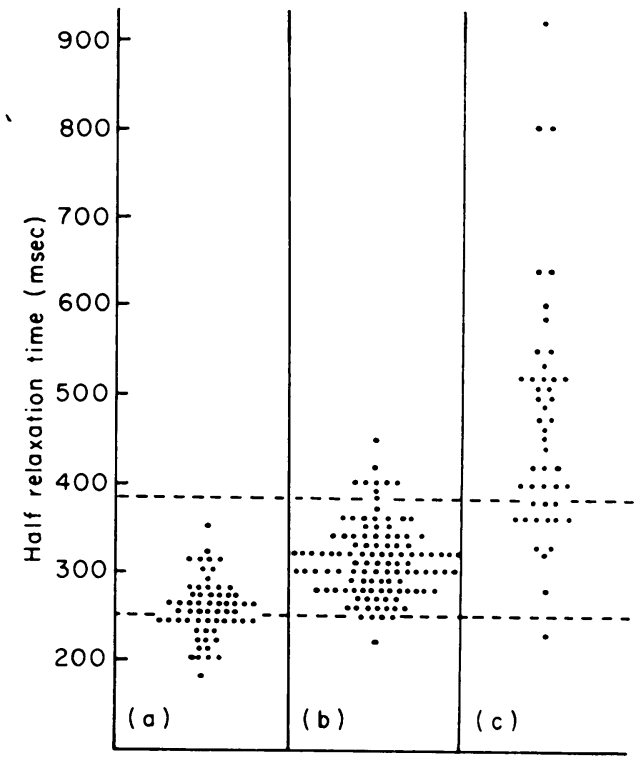

FIG. 3. The half-relaxation times in (a) sixty-two hyperthyroid, (b) 116 euthyroid and (c) forty-two hypothyroid patients. The dotted lines show two standard deviations of the mean for the euthyroid patients.

\section{Discussion}

Some workers have noted that the tendon reflex time may be longer in euthyroid women than men (Nuttall \& Doe, 1964; Reinfrank et al., 1967) although others have observed no such difference (Lambert et al., 1951 ; Robson, Hall \& Smart, 1965 ; Abraham, Atkinson \& Roscoe, 1966). We have found a small but significant increase in relaxation time in men matched for age with women. Most workers have found no correlation between age and the tendon reflex time (Lambert et al., 1951 ; Nuttall \& Doe, 1964 ; Abraham et al., 1966) but our results show a statistically significant lengthening of the relaxation time in those aged 50 or over, and this has been observed by others (Reinfrank et al., 1967).

These factors, however, are too small to effect materially the results obtained or to decide whether the tendon reflex time is a useful index of thyroidal function. The claims on this point are indeed conflicting (Lambert et al., 1951; 
Fogel et al., 1962 ; Nuttall \& Doe, 1964 ; Mann, 1963 ; Sherman et al., 1963 ; Miles \& Surveyor, 1965 ; Robson et al., 1965 ; Rives, Furth \& Becker, 1965 ; Abraham et al., 1966 ; Reinfrank et al., 1967). Some find that as many as $78 \%$ of their hyperthyroid and $38 \%$ of their hypothyroid patients have tendon reflex times within the normal euthyroid range (Rives et al., 1965) whereas others claim complete differentiation between hypothyroid patients and euthyroids and find that only $10 \%$ of hyperthyroid patients have normal reflex times (Abraham et al., 1966). Some workers believe that better discrimination is achieved with the kinemometer (Abraham et al., 1966), and measuring 'valley-to-peak' time (Fig. 1) by this technique does avoid inclusion of the nerve conduction time (Nuttall \& Doe, 1964). However the 'valley-to-peak' time in the kinemometer method approximates closely to the 'half-contraction-to-half-relaxation' time in the photomotogram (Fig. 1) which we have found even less reliable than the half-relaxation time (Table 2). Others have compared the results with the kinemometer and photomotogram methods directly and found no difference (Rives et al., 1965).

It seems probable that the wide variation in opinion as to the diagnostic value of the ankle reflex time is due to bias in the selection of cases rather than to differences in technique. In some series the patients have been selected because the diagnosis was beyond doubt and those with borderline abnormalities have deliberately been excluded (Lawson, 1958; Sherman et al., 1963 ; Mann, 1963). In one series many of the hypothyroid patients were selected for the test because their reflexes were thought to be clinically prolonged by the referring physician (Robson et al., 1965).

In the largest reported series Rives et al. (1965) used, like us, a number of parameters upon which final assessment of the thyroid function was based. They excluded from final analysis $20 \%$ of their patients, as opposed to our exclusion of $5 \%$, on grounds of uncertainty of dianosis. Even so their results show the poorest discrimination in the diagnosis of both hyperand hypo-thyroidism of all the published reports, although they are only slightly worse than ours (Table 4). These workers used a method of probit analysis, finding a normal distribution of their study population whereas we have found the distribution markedly skewed to the right; and this has been found by others (Robson et al., 1965). Analysis of results after logarithmic conversion gives significantly better diagnostic discrimination in our series but it is of interest to note that the figures for the HRT derived from the simple linear scale (Table 3) are almost identical to those of Rives et al. (Table 4): $76 \%$ compared with $78 \%$ of the hyperthyroid patients and $38 \%$ of the hypothyroid patients from both series falling into the euthyroid range. In the clinical situation involving assessment of an individual patient little is gained by these mathematical manoeuvres which cannot basically improve a relatively imprecise test, and in practice we use the linear arithmetic scale.

TABLE 4

Percentage of patients with normal relaxation time

\begin{tabular}{lccc}
\hline & $\begin{array}{c}\text { Hypo- } \\
\text { thyroid }\end{array}$ & $\begin{array}{c}\text { Hyper- } \\
\text { thyroid }\end{array}$ & Method \\
\hline Rives et al. (1965) & 38 & 78 & $\mathrm{~K}$ and P \\
Young (1964) & 60 & 60 & $\mathbf{P}$ \\
Lambert et al. (1951) & 23 & 75 & $\mathrm{~S}$ \\
Robson et al. (1965) & 12 & 69 & $\mathbf{E}$ \\
Nuki \& Bayliss (this study) & 27 & 62 & $\mathbf{P}$ \\
Sherman et al. (1963) & 6 & 23 & $\mathbf{P}$ \\
Reinfrank et al. (1967) & 28 & 8 & $\mathbf{P}$ \\
Abraham et al. $(1966)$ & 0 & 10 & $\mathbf{K}$ \\
Mann (1963) & 0 & 10 & $\mathrm{~K}$ \\
\hline
\end{tabular}

$\mathbf{P}=$ photomotogram, $\mathbf{K}=$ kinemometer, $\mathbf{S}=$ strain gauge transducer, $\mathrm{E}=$ electronic recorder.

The value of the Achilles tendon test is further limited by a number of conditions which may prolong the reflex time such as oedema (Harrell \& Daniel, 1941 ; Abraham et al., 1966), diabetes mellitus (Beardwood \& Schumacher, 1964), sarcoidosis (Richards, 1962), neurosyphilis (Simpson, Blair \& Nartowicz, 1963a), myasthenia gravis and schizophrenia (Simpson et al., 1963b), hypokalaemia (Carr et al., 1963), peripheral vascular disease (Galpin \& O'Brien, 1964), normal puerperium (Reinfrank et al., 1967), sprue (von Binswanger, Studer \& Wyss, 1961) and pernicious anaemia (Nuttall \& Doe, 1964). Some drugs may shorten the reflex time, namely amphetamine, ACTH, cortisone, oestrogens and salicylates (Lawson, 1958), adrenaline (Goldberg, 1962 ; Avera \& Overholt, 1962) as well as thyroid hormones. Bromides and antithyroid drugs may lengthen the time (Lawson, 1958).

The fact that the ankle reflex time gives some indication of the peripheral end-organ action of thyroid hormone, coupled with its simplicity, cheapness and immediate availability, makes it a useful adjunct to the clinical assessment of thyroid status provided its limitations are appreciated. The test is of value in following the response of the hypo- and hyper-thyroid patient to treatment. 


\section{Acknowledgment}

We wish to thank the Department of Chemical Pathology for their collaboration, and Dr Percy Cliffe for making the photomotogram. Part of the costs of this study were met by a grant from the Research Fund of the Westminster Hospital Board of Governors.

\section{References}

Abraham, A.S., Atrinson, M. \& Roscoe, B. (1966) Value of ankle-jerk timing in the assessment of thyroid function. Brit. med. J. i, 830.

Avera, J.W. \& Overholt, B.M. (1962) Achilles tendon reflex relaxation time. Amer. Practit. 13, 251.

BAYLISS, R.I.S. (1967a) Stimulation and suppression tests of thyroid function. Proc. roy. Soc. Med. 60, 303.

BAYLISS, R.I.S. (1967b) Stimulation and suppression tests of thyroid function. J. clin. Path. 20, 360.

Beardwood, D.M. \& Schumacher, L.R. (1964) Delay of the Achilles reflex in diabetes mellitus. Amer. J. med. Sci. 247, 324.

Carr, A.A., Gill, J.R., JR, Henkin, R.I. \& BartTer, F.C. (1963) The relationship of potassium metabolism to the Achilles tendon reflex in man. Clin. Res. 11, 215.

Chaney, W.C. (1924) Tendon reflexes in myxoedema: a valuable aid in diagnosis. J. Amer. med. Ass. 82, 2013.

FeJer, A.Gy. \& Kun, M. (1963) The Achilles reflex. (Letter). Lancet, ii, 695.

Fogel, R.L., Epstein, J.A., StopaK, J.H. \& Kupperman, H.S. (1962) Achilles tendon reflex (photomotogram) as a measure of thyroid function. N.Y. St. J. Med. 62, 1159.

Fournier, J.C.M. (1929) Trastornos del Sistema Nervioso de Origen Mixedematoso, p. 29. Barreiro y Ramos S.A., Montevideo.

Galpin, O.P. \& O'Brien, P.K. (1964) Prolongation of tendon reflexes in ischaemia. (Letter). Lancet, ii, 209.

GiLson, W.E. (1959) Achilles reflex recording with a simple photomotograph. New Engl. J. Med. 260, 1027.

GoldberG, M. (1962) Comparative study of the adrenergic potentiating properties of various thyroid analogs in man. J. clin. Endocr. 22, 892.

Harrell, G.T. \& Daniel, D. (1941) Delayed relaxation of tendon reflexes as an aid in the diagnosis of myxoedema. N.C. med. J. 2, 549.

Hobbs, J.R., Bayliss, R.I.S. \& Maclagan, N.F. (1963) The routine use of ${ }^{132} \mathrm{I}$ in the diagnosis of thyroid disease. Lancet, i, 8 .
LAMBert, E.H., UNderdahl, L.D., Beckett, S. \& MEderos, L.O. (1951) A study of the ankle jerk in myxoedema.J. clin. Endocr. 11, 1186.

LAwSON, J.D. (1958) The free Achilles reflex in hypothyroidism and hyperthyroidism. New Engl. J. Med. 259, 761.

MaNN, A.S. (1963) The value of kinemography in the diagnosis of thyroid dysfunction. Amer. J. med. Sci. 245, 317.

Miles, D.W. \& Surveyor, I. (1965) Role of the ankle-jerk in the diagnosis and management of thyroid disease. Brit. med. $J . \mathrm{i}, 158$.

Moulopoulos, S.D., Koutras, D.A. \& Kralios, A.C. (1964) A simple inexpensive method for recording Achilles tendon reflexes. Lancet, $\mathrm{i}, 85$.

Nutall, F.Q. \& Doe, R.P. (1964) The Achilles reflex in thyroid disorders. Ann. intern. Med. 61, 269.

ORD, W.M. (1884) On some disorders of nutrition related with affections of the nervous system. Brit. med. J. ii, 205.

Reinfrank, R.F., Kaufman, R.P., Wetstone, H.J. \& GlenNON, J.A. (1967) Observations of the Achilles reflex test. J. Amer. med. Ass. 199, 1.

Richards, A.G. (1962) The 'myxoedema reflex' as a presenting sign in sarcoidosis. Canad. med. Ass. J. 86, 32.

Rives, K.L., FuRTH, E.D. \& BeCKER, D.V. (1965) Limitations of the ankle jerk test: intercomparison with other tests of thyroid function. Ann. intern. Med. 62, 1139.

Robson, A.M., Hall, R. \& SMART, G.A. (1965) A critical evaluation of the tendon reflex measurement as an index of thyroid function. Postgrad. med. J. 41, 518.

Sharpe, A.R. (1961) A simple isotope method for recording the Achilles tendon reflex in myxoedema. J. Lab. clin. Med. $57,165$.

Sherman, L., Goldberg, M. \& Larson, F.C. (1963) The Achilles reflex. A diagnostic test of thyroid dysfunction. Lancet, i, 243.

Simpson, G.M., Blair, J.H. \& Nartowicz, G.R. (1963a) Prolonged Achilles reflex in neurosyphilis simulating the 'myxoedema reflex'. New Engl. J. Med. 268, 89.

Simpson, G.M., Blair, J.H. \& Nartowicz, G.R. (1963b) Diagnostic limitation of Achilles tendon reflex in thyroid disease. N.Y. St. J. Med. 63, 1148.

Smart, G.A. \& Robson, A.M. (1963) A simple method for recording Achilles tendon reflexes. Lancet, $\mathbf{i}, 363$.

von Binswanger, J., Studer, H. \& Wyss, F. (1961) Der Ablauf der Sehnenreflexebei Funktionsstörungen der Schilddrüse. Helv. med. Acta, 28, 482.

Young, J.A. (1964) The Achilles tendon reflex in thyroid disease. Scot. med. J. 9, 34

\title{
Recent trends in acute viral hepatitis
}

\author{
STUART J. SAUNDERS \\ Department of Medicine, University of Cape Town
}

ACUTE hepatitis is one of the most important infectious diseases to which man is prone. There is good evidence that a virus is the infective agent; but the offending virus or viruses continue to be elusive despite intensive efforts at isolation, both in vivo and in tissue culture (Rightsel, 1967). It is clear that the vital problems are the failure to propagate the infective agent in any host except man, and the consequent absence of any specific diagnostic serological test.

\section{Post-transfusion hepatitis}

While infective hepatitis is usually spread by ingestion, there has been increasing interest in viral hepatitis known to follow injections or similar manoeuvres, and the transfusion of blood, 